\title{
Morphological and sedimentological characterization of Honda temporary lake (southern Spain)
}

\author{
M.C. Castro ${ }^{1}$; M. Rivera ${ }^{2}$; M. Crespo²; J.M. Martín-García ${ }^{3}$ and F. Guerrero*1 \\ ${ }^{1}$ Departamento de Biología Animal, Vegetal y Ecología. Facultad de Ciencias Experimentales. Universidad de \\ Jaén. Campus Las Lagunillas s/n. 23071 Jaén. \\ 2 Departamento de Ingeniería Cartográfica, Geodesia y Fotogrametría. Escuela Politécnica Superior. Universidad \\ de Jaén. Avda. Madrid, 35. 23071 Jaén. \\ ${ }^{3}$ Departamento de Geología. Facultad de Ciencias Experimentales. Universidad de Jaén. Campus Las Lagunillas \\ s/n. 23071 Jaén. \\ * Corresponding author: fguerre@ujaen.es
}

\begin{abstract}
A bathymetric map, a morphometrical study based on bathymetry, and a sedimentological analysis of Honda Lake are carried out. Some relationships between morphometrical parameters and lake characteristics are presented. Results of the bathymetric map show that Honda Lake presents an ovoid outline form, with only one slightly convex basin. Phyllosilicates are the most abundant phases in the characterisation of the sediments, followed by gypsum and, in smaller proportions, by calcite, quartz, halite, and dolomite. Results obtained from the sediment texture shown that the most important texture in deep samples is silty-clay, while surface samples present higher proportions of silty-clay-loan. Finally we emphasise the importance of this study, in relation to possible future changes in morphometrical parameters as a consequence of human impact.
\end{abstract}

Keywords: Bathymetry, lake morphometry, sedimentology, saline lake, Andalusian endorheism, Spain.

\section{RESUMEN}

Se realiza un mapa batimétrico, un estudio morfométrico y un análisis sedimentológico de la laguna Honda, mostrándose algunas relaciones entre los parámetros morfométricos y las caracteristicas de la laguna. El mapa batimétrico muestra que la laguna Honda presenta una forma elipsoide, con un único vaso ligeramente convexo. Los filosilicatos son la fase más abundante en la caracterización del sedimento, seguido por yesos y en menor proporción por calcita, cuarzo, halita y dolomita. Los resultados obtenidos del análisis de la textura del sedimento muestran que la textura predominante en profundidad es la limo-arcillosa, mientras que las muestras de superficie presentan valores más altos de arcilla. Finalmente se remarca la importancia de este estudio en orden a posibles futuros cambios en la morfometría de la laguna a consecuencia de los impactos de origen humano.

Palabras clave: Batimetría, morfometría, sedimentología, lagos salados, endorreísmo andaluz, España.

\section{INTRODUCTION}

A limnological description of a lake is a necessary step in the research of an aquatic ecosystem and it includes the study of lake forms, their genesis and their role in a physical limnological perspective (Håkanson, 1981). In this sense, the morphology of a lake basin reflects processes closely related to its origin, which is a useful descriptor towards the classification of wetlands (Florín et al., 1993). In addition, morphometrical parameters exert a major control over a wide range of processes and features of a lacustrine ecosystem, and are fundamental in most limnological and hydrological projects.

One of the oldest limnological principles is that basin morphometry influences lake metabolism (Thienemann, 1925; Naumann, 1932). As a consequence, many studies have demonstrated how lake morphometry affects the rates of certain processes and the distribution of certain physical, chemical and biological parameters, 
such as lake trophic state (Pinel-Alloul et al., 1990), phytoplankton and submerged macrophyte abundance, structure and production (Schindler, 1971; Duarte \& Kalff, 1986, 1988; Pinel-Alloul et al., 1990), loading, dilution and recycling of nutrients (Pick and Lean, 1987), ratio of nitrogen to phosphorous (Smith, 1982), light climate (Sterner, 1990), sediment focusing (Blais \& Kalff, 1995), thermal structure (Robertson \& Ragotzkie, 1990), and dissolved humic matter (Eloranta, 1986), among others. In this sense, Guiral \& Pérez (1980) pointed out the importance of the cartography and morphometry of lake ecosystems as a first step in any kind of aquatic research.

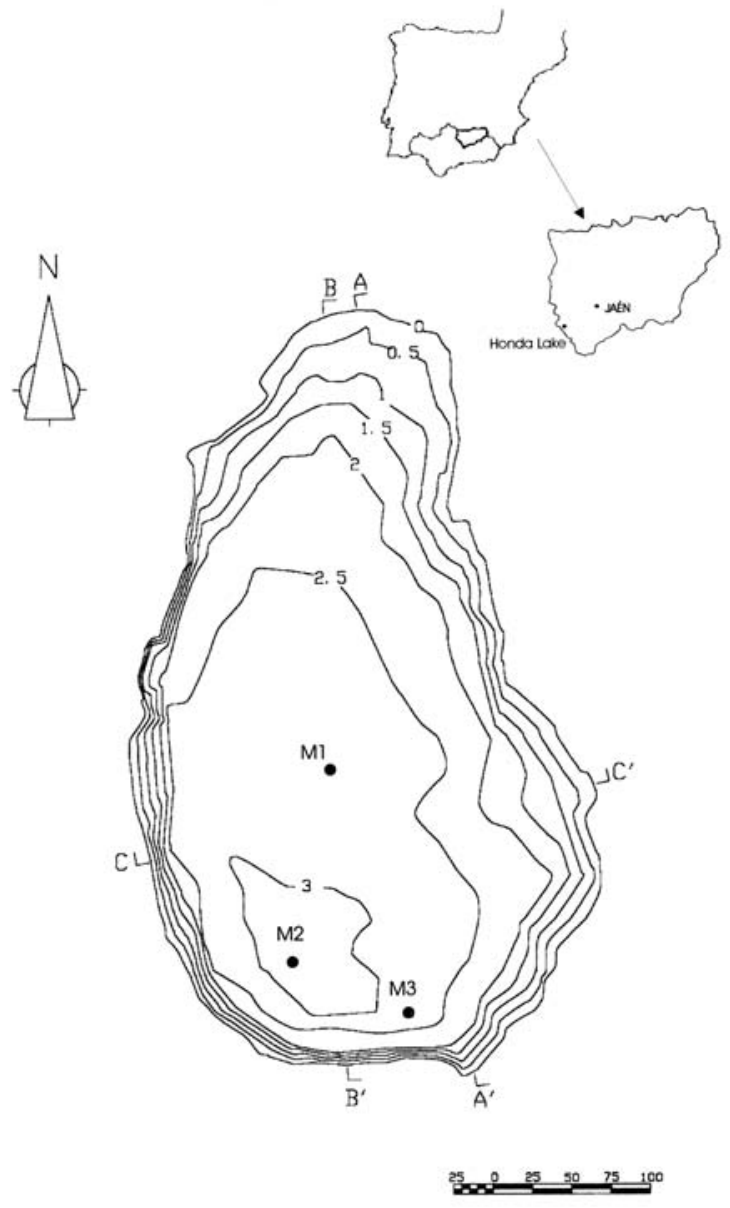

Figure 1. Geographic location of the Honda Lake, bathymetric map, and location of the sampling points (M1; M2 and M3). Localización geográfica de la laguna Honda, mapa batimétrico y situación de los puntos de muestreo (M1; M2 y M3).
However, most of the morphometric analyses carried out nowadays are based on measures of surface dimensions, but this type of study is insufficient to establish a good relationship with the physico-chemical and biological parameters of an aquatic ecosystem. That is why it would be necessary to include a more detailed analysis of morphometrical parameters of both, surface and subsurface dimensions.

In Spanish lakes there are few studies on morphometric lake parameters (see for example Rico et al., 1995). This study is intended to contribute to this type of knowledge by means of the morphometrical and sedimentological analysis and bathymetrical characteristics in Honda hypersaline lake (south-eastern Spain). This analysis complements some previous works (Guerrero \& Castro, 1997; López González et al., 1998), and can be used as a basis for future limnological studies.

\section{STUDY AREA}

Honda hypersaline lake is situated in southwestern Jaén (Fig. 1), close to the marshes of the Guadalquivir River (UTM-geographic coordinates: 30SVG992619), at 460 meters above sea level in an endorheic area. It is included in the Andalusian endorheism, with arid and semiarid climates. The Andalusian endorheism was characterised by Dantín (1940) and Pardo (1948), and is located on Triassic materials, that are mainly marls and clays. Deposits of evaporite (fundamentally gypsum and halits) are responsible for the hypersaline character of the lake (Castro, 1995). From a hydrological point of view, Honda Lake receives direct supply from rainfall, ground-water flow, and surface runoff from sporadic streams (Ingemisa, 1993).

\section{MATERIAL AND METHODS}

The construction of a bathymetric or contour map was performed in May 1999 by depth 
soundings made along transects by using a prism coupled with a Leica $805 / \mathrm{L}$ total station to a ranged pole. Depth measures were obtained from 17 diagonal transects. With the coordinates of all points, a computational digital terrain model was built, and a map at a scale 1:5000 was plotted. Contour intervals were $0.5 \mathrm{~m}$. We used SDR-VARIN 6.0 and AutoCAD R-14 software. The morphometric analysis followed Håkanson (1981).

In order to carry out a sedimentological characterisation, six sediment samples were collected in the dry season of the 1994-95 hydrological cycle, when the lake underwent complete desiccation and the maximum depth was less than $0.5 \mathrm{~m}$. Samples were taken at three different points (M1; M2 and M3), which are representative of the lake basin (Fig. 1) and at two depths [5 $\mathrm{cm}$ (S) and $30 \mathrm{~cm}$ (D)]. Granulometric analysis was carried out by sieving the sediment sample and subsequent sedimentation in a Robinson pipette, with the following fractions: clay $(<2 \mu \mathrm{m})$, silt $(2-50 \mu \mathrm{m})$ and sand $(50-2000 \mu \mathrm{m})$
(Soil Conservation Service, 1972). Gravel fractions $(>2 \mathrm{~mm})$ were not detected. Other analyses were carried out on the fine fractions of the sediment $(<2 \mathrm{~mm})$ : (i) organic carbon content by the dichromate oxidation method; (ii) $\mathrm{CaCO}_{3}$ equivalent by volume to Bernard's calcimeter; (iii) $\mathrm{pH}$ in a 1:1 fine fraction: water suspension (w/w), and (iv) electrical conductivity by the saturation extract method (Wolt, 1994). Organic matter content was estimated by multiplying organic carbon percentage by a correction factor of 1.724 (Soil Survey Staff, 1999).

The mineralogical composition of the fine sediment was determined by X-ray diffraction (XRD) in samples of un-oriented powder by using a holder filled from the side. A Siemens D-5000 diffractometer was used under the following operating conditions: radiation $(\mathrm{Cu} \mathrm{K \alpha})$ at $35 \mathrm{kV}$ and $15 \mathrm{~mA}$, time constant $2 \mathrm{~s}$.; step size $0.02^{\circ} 2 \theta$. Semi-quantitative analysis was determined by the intensity factors method (Klug \& Alexander, 1976), using the data published by De la Torre (1995).

Table 1. Morphometrical parameters of Honda lake (according to Håkanson, 1981). Parámetros morfométricos de la laguna Honda (según Håkanson, 1981).

$\begin{array}{lccc}\text { Area } & & \mathrm{a} & 99433 \mathrm{~m}^{2} \\ \text { Shoreline length } & \mathrm{F}=\mathrm{I}_{0} / 2 \pi \mathrm{ta} & \mathrm{I}_{\mathrm{o}} & 1322.12 \mathrm{~m} \\ \text { Shore development } & & \mathrm{F} & 1.18 \\ \text { Maximum length } & \overline{\mathrm{B}}=\mathrm{a} / \mathrm{L}_{\mathrm{MAX}} & \mathrm{L}_{\mathrm{MAX}} & 497.78 \mathrm{~m} \\ \text { Maximum width } & & \mathrm{B}_{\mathrm{MAX}} & 284.50 \mathrm{~m} \\ \text { Mean width } & \overline{\mathrm{B}} & 199.76 \mathrm{~m} \\ \text { Maximum depth } & \mathrm{D}_{\mathrm{MAX}} & 3.16 \mathrm{~m} \\ \text { Volume } & \overline{\mathrm{D}}=1000 \mathrm{~V}_{\mathrm{P}} / \mathrm{a} & \mathrm{V}_{\mathrm{p}} & 204726.39 \mathrm{~m}^{3} \\ \text { Mean depth } & \mathrm{D}_{\mathrm{r}}=\mathrm{D}_{\mathrm{MAX}} \bar{\pi} / 20 \sqrt{\mathrm{a}} & \mathrm{D}_{\mathrm{r}} & 2.06 \mathrm{~m} \\ \text { Relative depth } & & \mathrm{D}_{25} & 0.88 \% \\ \text { First quartile depth } & & \mathrm{D}_{50} & 2 \mathrm{~m} \\ \text { Median depth } & & \mathrm{D}_{75} & 1.25 \mathrm{~m} \\ \text { Third quartile depth } & & \alpha & 0.55 \mathrm{~m} \\ \text { Mean slope } & & \mathrm{V}_{\mathrm{d}} & 1.78 \% \\ \text { Volume development } & \mathrm{V}_{\mathrm{d}}=3 \overline{\mathrm{D}} / \mathrm{D}_{\mathrm{MAX}} & \mathrm{DR} & 1.96 \\ \text { Dynamic ratio } & \mathrm{DR}=\sqrt{\left(\mathrm{a} 10^{-6}\right) / \overline{\mathrm{D}}} & & 0.15 \\ \text { Direction of major axis } & & & \mathrm{S}-\mathrm{N} \\ \text { Lake form } & & \mathrm{SCx}-\mathrm{Lma}\end{array}$




\section{RESULTS AND DISCUSSION}

A bathymetric map is the standard way of recording the morphometry of lakes. The Honda bathymetric map (Fig. 1) shows an ovoid outline form, with one single basin. Table 1 shows the morphometrical parameters of Honda Lake. Among these parameters, mean depth $(\overline{\mathrm{D}})$ is probably the most useful morphometric feature available, because it could be related to the productivity and trophic status of lakes (Håkanson, 1981). It serves as a surrogate for most morphometric attributes and a host of biological processes, but no correlate can provide unambiguous information on underlying causes (Kalff, 2002). However, a high value of mean depth both in freshwater and in saline lakes, normally tends to show low levels of nutrients in water and consequently of productivity indicators such as chlorophyll- $a$ (ChowFraser, 1991; Sakamoto, 1966). Even though this parameter was developed to compare different lakes, we used it to evaluate changes in the same lake (Honda Lake) across two different hydrological cycles. Therefore we can see a very different ecosystem performance. In this way, during the 1994-95 hydrological cycle Honda Lake underwent complete desiccation. It shows a $\overline{\mathrm{D}}<0.3$, and chlorophyll- $a$ values, a common estimator of productivity or lake trophic status, were always higher than $225 \mu \mathrm{g} \mathrm{l}^{-1}$ (Guerrero \& Castro, 1997). On the other hand, in the 1998-99 hydrological cycle the lake did not become dry in the summer period and thus, mean depth value was higher $(\overline{\mathrm{D}}=1.4)$ and chlorophyll- $a$ values did not exceed $2 \mu \mathrm{g} \mathrm{l}^{-1}$.

Mean depth is greater than median depth $\left(\mathrm{D}_{50}\right)$, as it is characteristic of a slightly convex basin (see below). The median depth may be used to determine the lake bottom roughness, which is a useful parameter in sedimentological contexts and in the optimization models for lake hydrographical surveys (Håkanson 1981). Neumann (1959) concluded that the depth ratio $\left(\overline{\mathrm{D}} / \mathrm{D}_{\max }\right)$ provides a useful approximation to lake form. Honda Lake showed a value of 0.65 , similar to an ellipsoid form and it is characteristic of shallow lakes with flat bottoms (Carpenter, 1983). Honda Lake shows also a relative depth $\left(D_{r}\right)$, a parameter that may be used to describe stability of stratification of lakes, typical of small
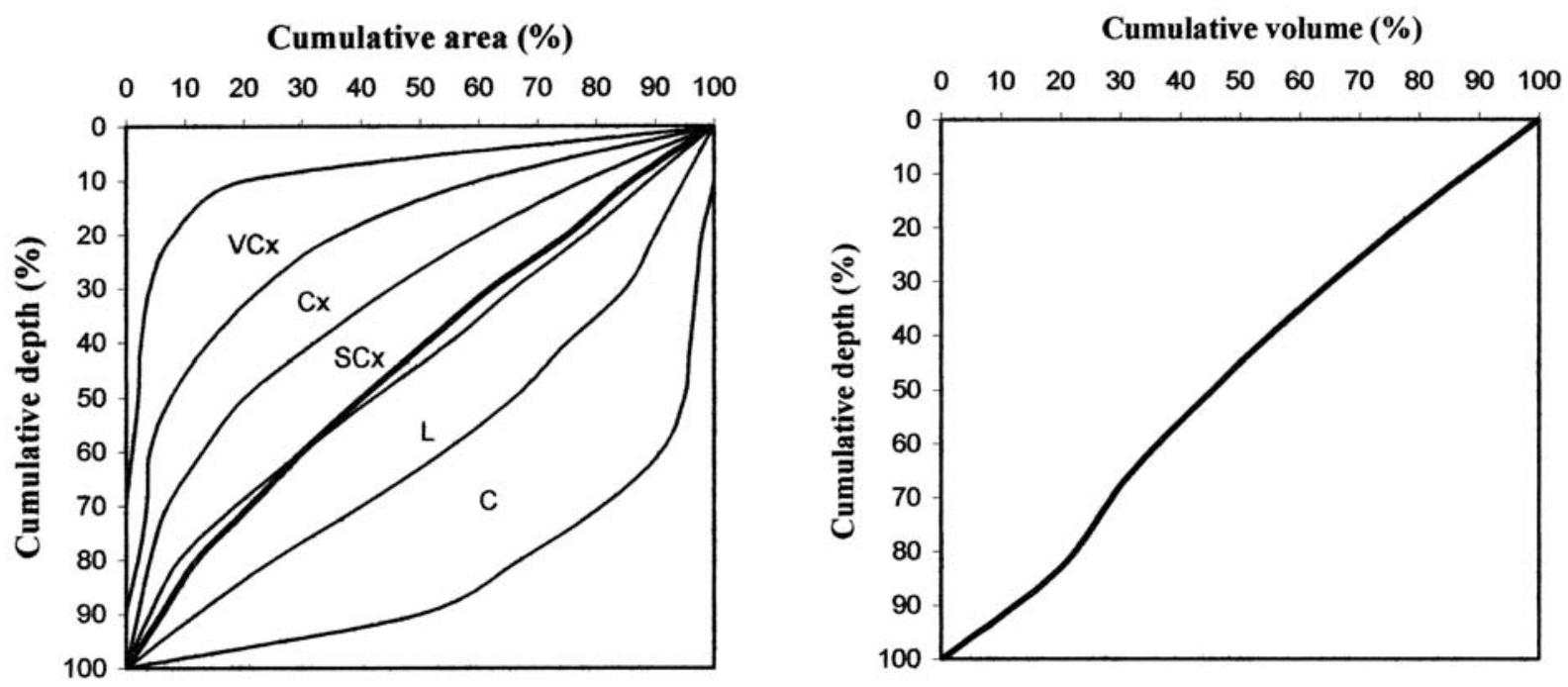

Figure 2. Relative hypsographic (A) and volume curves (B) for Honda lake (symbols and the class limit of lake morphologic classification system according to Håkanson, 1981). Curvas hipsográficas relativas (A) y de volumen (B) de la laguna Honda (simbología y límites de clases del sistema de clasificación morfológica de la laguna según Håkanson, 1981). 
Table 2. Mineralogical analysis (X-ray diffraction) of fine earth fraction $(<2 \mathrm{~mm})$; all values are \%. (tr: traces; $\mathrm{x}:<5 \%$; $\mathrm{xx}: 5-15 \%$; $\mathrm{xxx}$ : 15-30\%; xxxx: 30-45\%; xxxx: 45-60\%). Análisis mineralógico (difracción de rayos-X) de la fracción de tierra fina $(<2 \mathrm{~mm}$ ); todos los valores están en \%. (tr: trazas; $x$ : <5\%; xx: 5-15\%; xxx: 15-30\%; xxxx: 30-45\%; xxxxx: 45-60\%).

\begin{tabular}{lcccccc}
\hline & M1S & M1D & M2S & M2D & M3S & M3D \\
\hline Gypsum & $\mathrm{xxx}$ & $\mathrm{xxxx}$ & $\mathrm{xx}$ & $\mathrm{xxx}$ & $\mathrm{xxxx}$ & $\mathrm{xxxxx}$ \\
Phyllosilicates & $\mathrm{xxxxx}$ & $\mathrm{xxxxx}$ & $\mathrm{xxxxx}$ & $\mathrm{xxxxx}$ & $\mathrm{xxxx}$ & $\mathrm{xxx}$ \\
Quartz & $\mathrm{x}$ & $\mathrm{x}$ & $\mathrm{xx}$ & $\mathrm{x}$ & $\mathrm{x}$ & $\mathrm{xx}$ \\
Calcite & $\mathrm{x}$ & $\mathrm{x}$ & $\mathrm{xx}$ & $\mathrm{xx}$ & $\mathrm{x}$ & $\mathrm{x}$ \\
Dolomite & $\mathrm{x}$ & $\mathrm{x}$ & $\mathrm{x}$ & $\mathrm{x}$ & $\mathrm{x}$ & $\mathrm{xx}$ \\
Halite & $\mathrm{xx}$ & $\mathrm{x}$ & $\mathrm{x}$ & & $\mathrm{xx}$ \\
\hline
\end{tabular}

and shallow basins. Shore development (F) is near 1 and it represents a measure of the irregularity of the shoreline (Håkanson 1981), which is one of the morphological parameters that reflects processes related with lake origin. Salobral Lake, another shallow and temporary lake situated near Honda Lake, has an F value of 1.3 (Recio et al., 1985), as is normal for two basins which are originated by dissolution (Rico et al., 1995). Accordingly, the origin of Honda Lake could be connected with the karstic phenomena in gypsum and saline materials of the Trias.

Dynamic ratio (DR) is a morphometrical parameter designed to represent bottom dynamic conditions (Lindström et al., 1999). The influence of this parameter over processes such as lake desiccation and other processes related to the water-sediment interface denoted its importance. The dynamic ratio value $(\mathrm{DR}=0.15)$ indicates that has lower bottom areas exposed to wind/wave energy. In the same way, distribution coefficient $\left(\mathrm{V}_{\mathrm{d}} / 3\right)$ is a useful tool to know the amount of sediment available for re-suspension on the erosion and transport areas (ET-areas), the fraction that goes to deep waters, and the fraction $\left(1-\mathrm{V}_{\mathrm{d}} / 3\right)$ that goes to surface waters (Håkanson et al., 2000 ). The values obtained mean that $65.3 \%$ of the matter available can be assumed to be transported to deep waters and $34.7 \%$ to surface waters.

Honda Lake has slight shore slopes, although there is some dissimilarity between the two shorelines. The slight slope allows for colonisation of the sediment by submerged macrophytes and helophytes (Ortega \& Guerrero, 2003).

The hypsographic curve, that represents certain elements of the basin's form and provides a means whereby the area of any depth level may be determined (Håkanson 1981), indicates that the form of Honda Lake is slightly convex in the upper $3 / 4$ of its cumulative area, and linear in the lower 1/4 (Fig. 2). This curve may also be used in graphic determinations of the lake volume. In this sense, sixty per cent of the total volume is located in the first upper meter.

In relation to sedimentological characterisation, the minerals that were determined in the sediment are: phyllosilicates (mainly mica and chlorite); quartz; gypsum; calcite; halite and dolomite (Table 2). Semi-quantitative analysis shows mainly that phyllosilicates are the most abundant phases, followed by gypsum and, in smaller and decreasing proportions, by calcite, quartz, halite, and dolomite. Gypsum was the only analysed mineral that showed a consistent pattern of increased proportions with depth. All other minerals showed either no changes with depth or no consistent pattern of change with depth among sample locations. This mineralogical composition is very similar to that of Salobral Lake (Recio et al., 1995), due to the Triassic materials of Keuper that crop out in both basins (Ingemisa, 1993).

Results obtained from the sediment show that silty-clay is the most important texture in deep 


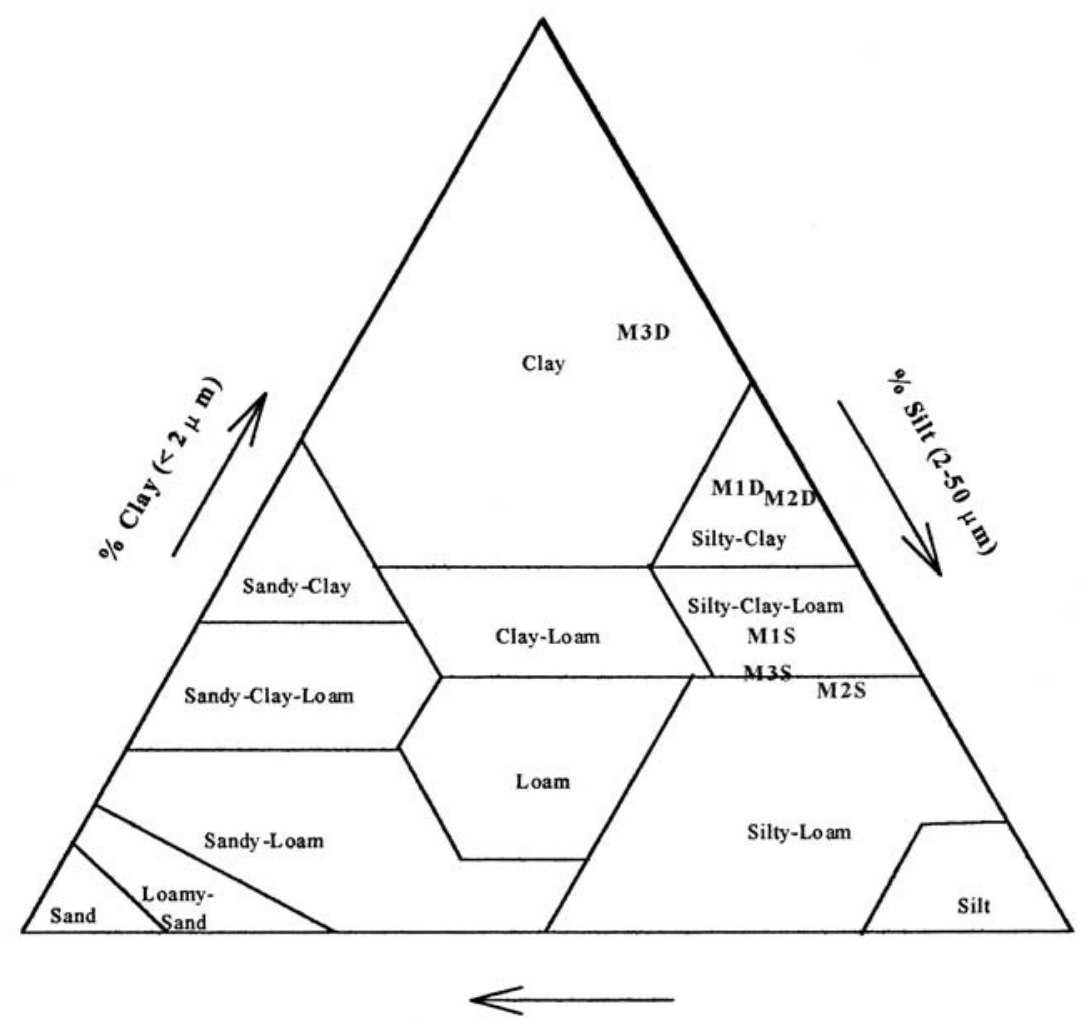

\% Sand $(50-2000 \mu m)$

Figure 3. Textural classification of the sediments according to USDA (1972). Clasificación de la textura de los sedimentos de acuerdo con USDA (1972).

samples (Fig. 3), while surface samples present mainly a silty-clay-loam texture. Table 3 shows the values of $\mathrm{pH}$, conductivity, percentage of equivalent calcium carbonate, and organic matter content from sediment samples from 5 and $30-\mathrm{cm}$. of depth. Honda presents an irregular distribution with depth in these parameters, with higher values always at $30-\mathrm{cm}$. of depth, except in conductivity. The comparison with the results obtained by Vargas et al. (1983) in Fuente de Piedra saline Lake allows us to appreciate the differences between both lakes, with lower values of calcium carbonate in Honda Lake and higher values in organic matter content, with maximum values over 2 and $16 \%$ respectively.

The organic matter distribution with depth, with maximum values at $30-\mathrm{cm}$. and minimum at 5-cm. depth, allows us to think about

Table 3. Some characteristics of the sediment of Honda lake (O.M.= organic matter). Algunas caracteristicas del sedimento de laguna Honda $($ O.M. = materia orgánica $)$.

\begin{tabular}{lrrrrrr}
\hline & M1S & M1D & M2S & M2D & M3S & M3D \\
\hline Conductivity $\left(\mathrm{S} \mathrm{cm}^{-1}\right)$ & 11.7 & 7.5 & 11.0 & 6.0 & 8.8 & 7.7 \\
pH & 7.6 & 7.9 & 7.6 & 7.7 & 7.3 & 7.8 \\
$\mathrm{CaCO}_{3}$ equiv (\%) & 10.1 & 13.3 & 12.2 & 17.7 & 8.2 & 18.5 \\
O.M. (\%) & 2.3 & 14.1 & 5.7 & 15.8 & 3.6 & 11.9 \\
\hline
\end{tabular}


the influence of basin silting, the most important human impact affecting this ecosystem, mainly due to an inadequate olive tree tillage on its shorelines (Montes \& Martino, 1987; García Fuentes et al., 1996; Ortega et al., 2003). This implies changes in morphometry parameters and destruction and substitution of littoral plant communities around the lake. Thus, we want to emphasise the importance of this study in terms of possible future changes in morphometrical parameters as a consequence of human impact.

\section{REFERENCES}

BLAIS, J.M. \& J. KALFF. 1995. The influence of lake morphometry on sediment focusing. Limnol. Oceanogr., 40: 582-588.

CARPENTER, S. R. 1983. Lake geometry: Implications for production and sediment accretion rates. Journal of Theoretical Biology, 105: 273-286.

CASTRO, M. C. 1995. Cambios en la comunidad planctónica en una laguna hipersalina durante un año de escasas precipitaciones. Memoria de iniciación a la investigación, Universidad de Jaén. 111 pp.

CHOW-FRASER, P. 1991. Use of the morphoedaphic index to predict nutrient status and algal biomass in some Canadian lakes. Canadian Journal of Fisheries and Aquatic Science, 48: 1909-1918.

DANTÍN, J. 1940. La aridez y el endorreísmo en España. El endorreísmo bético. Estudios Geográficos, 1: 75-117.

DE LA TORRE, M. J. 1995. Estudio de los materiales de construcción en la Alambra. Servicio de Publicaciones de la Universidad de Granada, Granada.

DUARTE, C. M. \& J. KALFF. 1986. Littoral slope as a predictor of the maximum biomass of submerged macrophyte communities. Limnol. Oceanogr., 31: 1072-1081.

DUARTE, C. M. \& J. KALFF. 1988. Influence of lake morphometry on the response of submerged macrophytes to sediment fertilization. Canadian Journal of Fisheries and Aquatic Science, 45: 216-221.

ELORANTA, P. 1986. Phytoplankton structure in different lake types in central Finland. Holartic Ecology, 9: 214-224.
FLORÍN, M., C. MONTES \& F. RUEDA. 1993. Origin, hydrologic functioning, and morphometric characteristics of small, shallow, semiarid lakes (lagunas) in La Mancha, central Spain. Wetlands, 13 (4): 247-259.

GARCÍA FUENTES, A., J. NIETO, J. A. TORRES \& E. CANO. 1996. Estudio de la vegetación de Laguna Honda (Jaén, España). I Colóquio Internacional de Ecologia da vegetaçao, Evora, Portugal: 341-352.

GUIRAL, J. \& E. PÉREZ. 1980. Sobre un esquema de trabajo e índice de estudio para proyectos de protección de zonas húmedas. Boletín de la Estación Central de Ecología, 9: 19- 26.

GUERRERO, F. \& M. C. CASTRO. 1997. Chlorophyll- $a$ of size-fractionated phytoplankton at a temporary hypersaline lake. International Journal of Salt Lake Research, 5: 253-260.

HÅKANSON, L. 1981. A manual of lake morphometry. Berlin: Springer-Verlag.

HÅKANSON, L., A. PARPAROV \& K. D. HAMBRIGHT. 2000. Modelling the impact of water level fluctuations on water quality (suspended particulate matter) in Lake Kinneret, Israel. Ecological Modelling, 128: 101-125.

INGEMISA. 1993. Criterios para la elaboración de los planes de ordenación de los recursos naturales en las reservas y parajes naturales. Reserva natural de la laguna Honda. Junta de Andalucía. 78 pp. (Unpublished).

KALFF, J. 2002. Limnology. New Jersey: Prentice Hall.

KLUG, H. P. \& L. E. C. ALEXANDER. 1976. X-ray diffraction procedures for polycrystalline and amorphous material. New York: John Wiley \& Sons.

LINDSTRÖM, M., HÅKANSON, L., O. ABRAHAMSSON \& H. JOHANSSON. 1999. An empirical model for prediction of lake water suspended particulate matter. Ecological Modelling, 121: 185-198.

LÓPEZ GONZÁlEZ, P., F. GUERRERO \& M. C. CASTRO. 1998. Seasonal fluctuations in the plankton community in a hypersaline temporary lake (Honda, southern Spain). International Journal of Salt Lake Research, 6: 353-371.

MONTES, C. \& P. MARTINO. 1987. Las lagunas salinas españolas. In: Bases científicas para la protección de los humedales en España. Real Academia de Ciencias Exactas, Físicas y Naturales (ed.): 95-145. Madrid, España. 
NAUMANN, E. 1932. Grundzuge der regionalen Limnologie. Binnengewässer, 11 (9): 1-176.

NEUMAN, J. 1959. Maximum depth and average depth of lakes. Canadian Journal Fish Research Board, 16: 923-927.

ORTEGA, F. \& F. GUERRERO. 2003. Vegetación de las lagunas y humedales del Alto Guadalquivir. El complejo lagunar de Alcaudete-Valenzuela. In: In Memoriam al profesor Dr. Isidoro Ruiz Martínez. J.M ${ }^{a}$ Pérez Jiménez (ed.). Universidad de Jaén, Jaén, España: 101-106.

ORTEGA, F., G. PARRA \& F. GUERRERO. 2003. Los humedales del Alto Guadalquivir: inventario, tipologías y estado de conservación. In: Ecología, manejo y conservación de los humedales. M. Paracuellos (ed.). Instituto de Estudios Almerienses (Diputación de Almería), Almería, España: 113-123.

PARDO, L. 1948. Catálogo de los lagos de España. Biología de las Aguas Continentales VI. Instituto Forestal de Investigaciones Experimentales. Madrid. 522 pp.

PICK, F. F. A. \& C. W. LEAN. 1987. The role of macronutrients $(\mathrm{C}, \mathrm{N}, \mathrm{P})$ in controlling cyanobacterial dominance in temperate lakes. New Zealand Journal of Marine and Freshwater Research, 21: 425-434.

PINEL-ALLOUL, B., G. MÉTHOT, G. VERRAULT \& Y. VIGNEAULT. 1990. Phytoplankton in Quebec lakes: variation with lake morphometry, and with natural and anthropogenic acidification. Canadian Journal of Fisheries and Aquatic Science, 47: 1047-1057.

RECIO, J. M., A. GARCÍA-FERRER \& M. SÁNCHEZ DE LA ORDEN. 1985. La laguna del Conde o del Salobral (Luque, Córdoba). Boletín de la Estación Central de Ecología, 14: 57-64.

RICO, E., A. CHICOTE, M. E. GONZÁLEZ \& C. MONTES. 1995. Batimetría y análisis mor- fométricos del lago de Arreo (N. España). Limnética, 11 (1): 55-58.

ROBERTSON, D. M. \& R. A. RAGOTZKIE. 1990. Thermal structure of a multibasin lake: influence of morphometry, interbasin exchange and groundwater. Canadian Journal of Fisheries and Aquatic Science, 47: 1206-1212.

SAKAMOTO, M. 1966. Primary production by phytoplankton community in some Japanese lakes and its dependence on lake depth. Archiv für Hydrobiology, 62: 1-28

SCHINDLER, D. W. 1971. A hypothesis to explain differences and similarities among lakes in the Experimental Lakes Area, northwestern Ontario. Journal of Fish Research Board of Canada, 28: 295-301.

SMITH, V. H. 1982. The nitrogen and phosphorus dependence of algal biomass in lakes: an empirical and theoretical analysis. Limnology and Oceanography, 27: 1101-1112.

SOIL CONSERVATION SERVICE. 1972. Soil survey laboratory methods and procedures for collecting soil samples. US Department of Agriculture, Washington, DC., USA.

SOIL SURVEY STAFF. 1999. Keys to soil taxonomy. Soil Conservation Service, USDA, Pocahontas Press, Blacksburg, VA.

STERNER, R. W. 1990. Lake morphometry and light in surface layer. Canadian Journal of Fisheries and Aquatic Science, 47: 687-692.

THIENEMANN, A. 1925. Die Binnengewässer Mitteleuropas. Binnengewässer, 1: 1-255.

VARGAS, J. M., M. BLASCO \& A. ANTÚNEZ. 1983. Los vertebrados de la laguna de Fuente de Piedra. ICONA. Monografía 28. Madrid, España. WOLT, J. D. 1994. Soil Solution Chemistry: application to environmental science and agriculture. New York: John Wiley \& Sons. 